\title{
Sulphur as a nutrient for Merino sheep
}

\author{
2.* The utilization of sulphur in forage diets
}

\author{
By J. P. LANGLANDS AND H. A. M. SUTHERLAND \\ CSIRO, Division of Animal Physiology, Pastoral Research Laboratory, \\ Armidale, NSW 2350, Australia \\ AND M. J. PLAYNE \\ CSIRO, Division of Tropical Agronomy, Pastoral Research Laboratory, \\ Townsville, Queensland 481о, Australia \\ (Received 16 Fanuary 1973-Accepted 4 May 1973)
}

\begin{abstract}
I. Faecal and urinary sulphur excretions of Merino sheep given fifty-one forage diets were measured in 205 balance experiments to derive estimates of the dietary requirements of Merino sheep for $\mathbf{S}$.

2. Faecal $\mathbf{S}$ excretion varied with the $S$, organic matter and digestible organic matter intakes. Non-dietary faecal $\mathrm{S}$ excretion was estimated by regression analysis and was approximately $0.7 \mathrm{~g} \mathrm{~S} / \mathrm{kg}$ organic-matter intake. Apparent S digestibility declined linearly with the reciprocal of dietary $S$ content, and was predicted to be zero when the dietary $S$ content was $0.81 \mathrm{~g} \mathrm{~S} / \mathrm{kg}$ organic matter.

3. Both urinary $S$ excretion and $S$ retention varied with the digestible $S$ and digestible organic-matter intakes. Endogenous urinary $S$ excretion was taken to be the urinary $S$ excretion when digestible $S$ intake was zero, and the sheep was at zero energy balance. It was estimated by regression analysis to be $38 \mathrm{mg} \mathrm{S} / \mathrm{d}$.

4. The $S$ and digestible $S$ intakes necessary to maintain the fleece-free tissues in $S$ equilibrium can be calculated from the equations derived in this study. An example is presented.
\end{abstract}

Langlands \& Sutherland (1973) reported estimates of sulphur secretion during growth, pregnancy, wool and milk production. The values can be used to calculate $S$ requirements in conjunction with estimates of the losses of $S$ in urinary and faecal excretions. These estimates were derived from an analysis of $20_{5} \mathrm{~S}$-balance experiments in which fifty-one temperate and tropical forages were given to Merino sheep. The results were assumed to be representative of forages in general, and were examined as a single set. In some instances the results were collected primarily to make comparisons between particular forages, fertilizer treatments or times of year, and these comparisons will be reported elsewhere (cf. Playne \& Haydock, 1972).

\section{EXPERIMENTAL}

\section{General}

One hundred and nine balance experiments were undertaken at the CSIRO, Pastoral Research Laboratory, Armidale with temperate forages which were principally Avena sativa L., Medicago sativa L., Lolium perenne L., Trifolium repens L., Phalaris tuberosa L., Poa labillardieri, Danthonia D.C. and Bothriochloa L.

\footnotetext{
* Paper no. I: Br. F. Nutr. (1973), 30, 529.
} 
species. Ninety-six balance experiments were conducted with tropical forages at the CSIRO, Pastoral Research Laboratory, Townsville; the principal species were Heteropogon contortus P. Beauv., Stylosanthes humilis and Urochloa mosambicensis Beauv.

Adult Merino wethers with a mean live weight of $35 \mathrm{~kg}$ were used in all experiments and were drenched regularly with an anthelmintic. The forages were either cut, chopped and frozen, or cut and dried. They were given for a preliminary period of 7-Io d, and this was followed by a collection period of similar length. In some experiments forages were given $a d$ lib., and in others intake was restricted. Water was given $a d l i b$. and was either distilled or had been found by analysis to contain negligible quantities of $\mathrm{S}$ and nitrogen.

Food, food residues and faeces were oven-dried at either $70^{\circ}$ or $100^{\circ}$ and milled before analysis; faecal output was determined by total collection. Urine was collected and preserved in hydrochloric acid to bring the $\mathrm{pH}$ to not more than $\mathbf{~}$. It was frozen as soon as possible after collection, and was thawed before analysis.

\section{Analyses}

All samples were analysed at Armidale. Food, food residues and faeces were analysed for $\mathrm{N}$, organic matter and $\mathrm{S}$ contents, and urine for $\mathrm{N}$ and $\mathrm{S}$. $\mathrm{N}$ was determined by a semi-micro-Kjeldahl procedure with selenium as a catalyst. Samples were digested in nitric and perchloric acids for $S$ determination, and were then allowed to react with barium chloride in an automated analytical system as described by Mottershead (I97I).

\section{RESULTS}

\section{General}

The mean and range in $\mathrm{N}, \mathrm{S}$ and organic-matter intakes and excretions are summarized in Table $\mathbf{I}$. There were highly significant $(P<0.00 \mathrm{I})$ positive correlations between dietary $\mathrm{N}$ and $\mathrm{S}$ contents $(r=+0.86)$, and between these variables and the organic-matter digestibility of the diet $(r=+0 \cdot 79$ in both instances). Organic-matter digestibility was significantly correlated with $\mathrm{N}(r=+0.86)$ and $\mathrm{S}$ digestibility $(r=+0 \cdot 74)$.

\section{Faecal S excretion (FS)}

FS (g/d) varied with the $S$ intake (SI, $g / d$ ), organic matter (OMI, g/d) and digestible organic matter (DOMI, $g / d$ ) intake:

$$
\mathrm{FS}=0.18 \mathrm{ISI}+0.00102 \mathrm{OMI}-0.00072 \mathrm{DOMI} \text {. }
$$

The residual standard deviation was $0.09 \mathrm{~g} / \mathrm{d}$, the intercept was not significant, and the standard errors of the regression coefficients for SI, OMI and DOMI were $0.017,0.00007$ and 0.00016 respectively. All coefficients were highly significant $(P<0.001)$. Since OMI equals DOMI plus the faecal organic matter output, the faecal organic matter output and either DOMI or OMI could be taken as independent variables in place of OMI and DOMI without affecting the precision or the regression 
Table I. Mean and range for nitrogen, sulphur and organic-matter intakes and excretions of the sheep

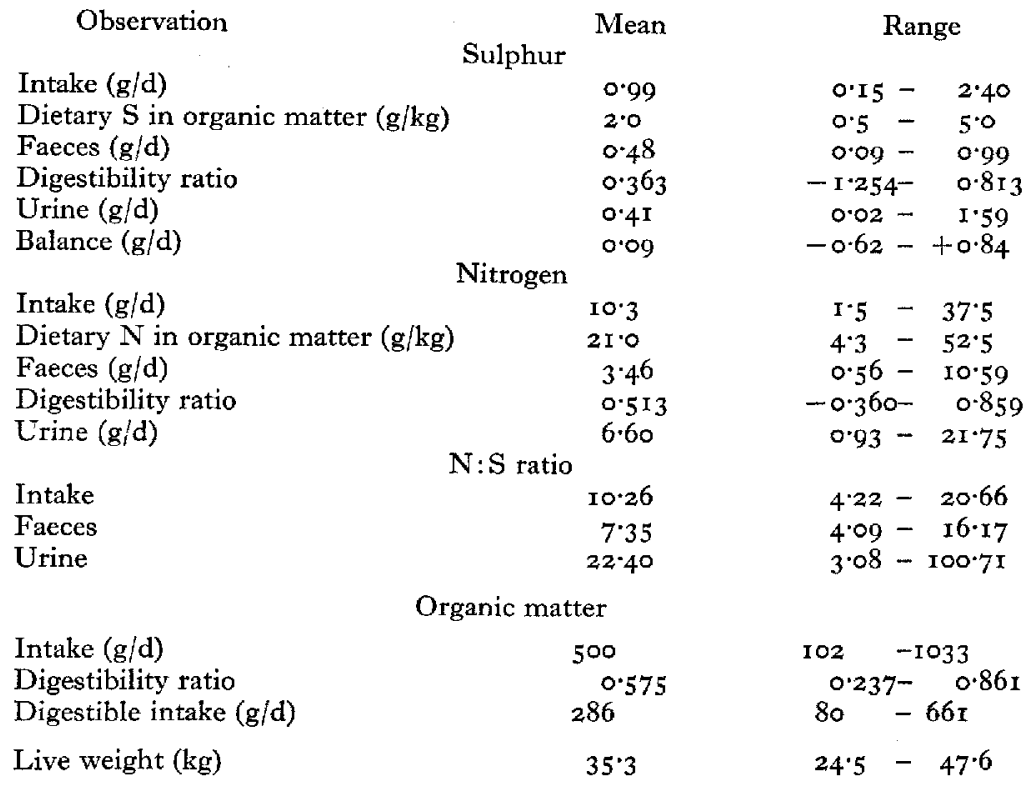

coefficient for SI in equation (I). Residual variability was not markedly increased when the independent variable, DOMI was deleted from equation (I) to give:

$$
\mathrm{FS}=0.124 \mathrm{SI}+0.00072 \mathrm{OMI} \text {. }
$$

The residual standard deviation of equation (2) was $0.095 \mathrm{~g} / \mathrm{d}$, and the intercept was not significant. The standard errors of the regression coefficients for SI and OMI were 0.012 and 0.00003 . If the relationship between FS, SI and OMI is of the form given in equation (2), it can be shown (Van Niekerk, Smith \& Oosthysen, 1967) that the relationship between the apparent digestibility of forage S (SDIG) and the reciprocal of the forage $\mathrm{S}$ content (HS, $\mathrm{g} \mathrm{S} / \mathrm{kg}$ organic matter) will be linear:

$$
\mathrm{SDIG}=0.844-0.68 \mathrm{I} / \mathrm{HS} \text {. }
$$

The residual standard deviation of equation (3) was $0 \cdot 15$ units, the standard error of the regression coefficient 0.025 , and the correlation coefficient, $-0.89(P<0.001)$. The individual observations are presented in Fig. I. The regression coefficients for OMI in equation (2) and for the reciprocal of HS in equation (3) provide estimates of the non-dietary faecal S excretion (NDFS, g/kg OMI); these estimates were 0.72 (equation (2)) and $0.68 \mathrm{~g} \mathrm{~S} / \mathrm{kg}$ OMI.

\section{Urinary $S(U S)$ excretion}

US excretion ( $\mathrm{g} / \mathrm{d}$ ) was related to several variables using multiple regression analysis. Independent variables were deleted when not significant using the 'backward elimination procedure' described by Draper \& Smith (I966). Most of the 


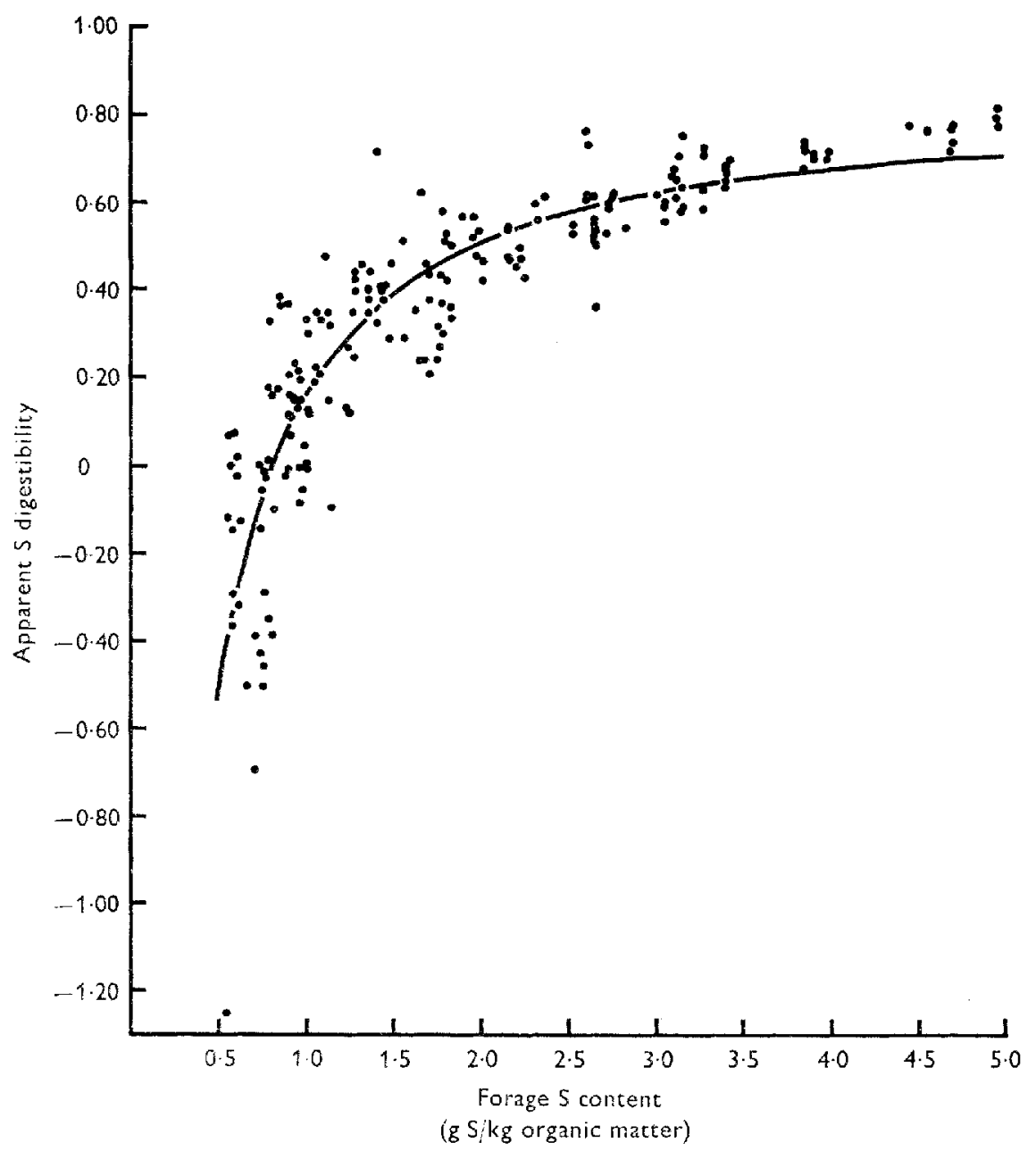

Fig. r. Relationship in sheep between apparent sulphur digestibility and the $\mathrm{S}$ content of the forage. The fitted regression line is equation (3) (see p. 539).

variability in US excretion was associated with digestible S (DSI, g/d) and DOMI. The regression coefficients for the squares and product of these terms were not significant. The intercept was assumed to represent endogenous US and $\mathrm{S}$ arising from tissue catabolism. The relationship was recalculated in an attempt to isolate the endogenous US excretion by substituting the DOMI in excess of the maintenance energy requirements $\left(D^{\circ O M I} I_{m}, g / d\right)$ as the second independent variable. The intercept is then an extrapolated estimate of US excretion when DSI is zero, and the sheep is at zero energy balance. It has been taken to be an estimate of endogenous US excretion:

$$
\mathrm{US}=0.704 \mathrm{DSI}-0.000424 \mathrm{DOMI}+0.038 .
$$

The relationship was significant $(P<0.001)$, the residual standard deviation was $0 . \mathrm{I} 6 \mathrm{~g}, R^{2}$ was $0.8 \mathrm{I}$, and the standard errors of the regression coefficients for DSI 
and $\mathrm{DOMI}_{\mathrm{m}}$ were 0.028 , and $0.000 \mathrm{II} 7$ respectively. The maintenance requirements for energy measured in $\mathrm{g} D \mathrm{DOMI} / \mathrm{d}$ were calculated from the expression $2.7^{7} \mathrm{~W}^{0.73}$, where $\mathrm{W}$ is live weight $(\mathrm{kg})$; the expression was taken from the results of Langlands, Corbett, McDonald \& Pullar ( 1963 ). The endogenous US excretion was $38 \mathrm{mg} \mathrm{S} / \mathrm{d}$. Endogenous urinary N excretion is sometimes (Agricultural Research Council, 1965) expressed relative to $W^{0.73}$, and a value of $2 \cdot 82 \mathrm{mg} \mathrm{S} / \mathrm{W}^{0.73}$ was obtained when endogenous US was calculated in this way.

\section{$D S I$ and $S$ retention (balance) $(S B A L)$}

The regression relationship between SBAL ( $\mathrm{g} / \mathrm{d})$, DSI and $\mathrm{DOMI}_{\mathrm{m}}$ can be derived directly from equation (4):

and can be rearranged to give:

$$
\mathrm{SBAL}=0.296 \mathrm{DSI}+0.000424 \mathrm{DOMI}_{\mathrm{m}}-0.038
$$

$$
\mathrm{DSI}=3.378 \mathrm{SBAL}-0.00142 \mathrm{DOMI}_{\mathrm{m}}+0.128 .
$$

Equation (6) differs from the regression of DSI on SBAL and DOMI $m$ but the method of calculation adopted was preferred because DSI cannot logically be regarded as being determined by the quantity of $S$ retained, and because errors of measurement of DSI and DOMI $\mathrm{m}$ were likely to be smaller than those of SBAL. In a similar situation, Robinson \& Forbes (1966) calculated a functional relationship but the magnitudes of the errors of measurement associated with DSI, SBAL and DOMI $_{\mathrm{m}}$ are required for such a calculation and these were not available. The DSI at zero energy balance associated with SBAL of $0,0 . \mathrm{I}$ and $0.2 \mathrm{~g} / \mathrm{d}$ were calculated from equation (6) to be $0.13,0.47$ and $0.80 \mathrm{~g} \mathrm{DSI} / \mathrm{d}$ respectively.

\section{DISCUSSION}

The forages varied widely in $\mathrm{S}$ and $\mathrm{N}$ concentrations, and in digestibility, and were given at varying levels of intake to induce large differences in FS and US excretions (Table I). Dietary $\mathrm{S}$ was excreted mainly in the faeces and FS exceeded DSI when forages contained less than $0.8 \mathrm{I} \mathrm{g} \mathrm{S} / \mathrm{kg}$ organic matter (equation (3)). This value can be compared with that of $\mathrm{I} \cdot \mathrm{I} 4 \mathrm{~g} \mathrm{~S} / \mathrm{kg}$ dry-matter intake reported by Barrow \& Lambourne (1962). Negative values of SDIG at low levels of HS can be attributed to the excretion of $S$ of non-dietary origin. $S$ derived from tissue catabolism and other sources passes into the gastrointestinal tract and may be synthesized into microbial protein. The digestibility of $S$ in microbial protein in the hind gut is approximately 0.7 (Bird, $1972 a$ ), and therefore approximately one-third of the microbial $\mathrm{S}$ is excreted in the faeces. It is assumed that when $\mathrm{S}$ intake is low, microbial $\mathrm{S}$ is an important component of the FS and of the NDFS since bile and pancreatic secretions are largely reabsorbed from the gastrointestinal tract (Bird, 1972b). A similar mechanism operates with $\mathrm{N}$ and is responsible for the raised metabolic faecal $\mathrm{N}$ excretion of ruminants relative to non-ruminants (Hogan \& Weston, 1968). The metabolic faecal $\mathrm{N}$ excretion of sheep is $5 \mathrm{~g} \mathrm{~N} / \mathrm{kg}$ dry-matter intake (Agricultural Research Council, I965) which is equivalent to approximately $5.6 \mathrm{~g} \mathrm{~N} / \mathrm{kg}$ OMI. 
The N:S ratio for the non-dietary faecal excretion is therefore $5 \cdot 6: 0.7$ or 8 , which is similar to the mean faecal N:S ratio of $7 \cdot 4$ found in the present study but is less than the corresponding ratio of approximately i f for rumen bacterial and protozoal fractions (Walker \& Nader, 1968 ). Presumably the $\mathrm{S}$ moiety of the rumen fractions is less digestible than the $\mathrm{N}$ fraction, or some non-bacterial component of the NDFS has a low $\mathrm{N}: \mathrm{S}$ ratio.

US excretion varied with the quantity of $S$ absorbed and with the quantity of digestible organic matter consumed. Elliott, Reed \& Topps (1964) varied energy and digestible $\mathrm{N}$ intakes of steers and found live-weight gain and, therefore, presumably $\mathrm{N}$ balance and urinary $\mathrm{N}$ excretion varied with digestible $\mathrm{N}$ intake and its square, energy intake and the product, energy $\times$ digestible $\mathrm{N}$ intake. This and similar models with $\mathrm{S}$ substituted for $\mathrm{N}$ were examined in this study but the quadratic and product terms were not significant. The intercept of equation (4), $3^{8} \mathrm{mg} \mathrm{S} / \mathrm{d}$, was the predicted US excretion when the sheep was at energy balance and when DSI was zero; it was regarded as an estimate of the endogenous US excretion. Walker \& Faichney (I964) estimated the mean ratio of endogenous urinary $\mathrm{N}: \mathrm{S}$ to be 27.8 for lambs, and if the endogenous urinary $\mathrm{N}$ excretion of our sheep is to be taken to be $90 \mathrm{mg}$ $\mathrm{N} / \mathrm{kg}$ live weight ${ }^{\circ 73}$ (Agricultural Research Council, $19^{6} 5$ ) and a $\mathrm{N}: \mathrm{S}$ ratio of 27.8 is assumed, the endogenous US excretion would be $3.24 \mathrm{mg} \mathrm{S} / \mathrm{kg}$ live weight ${ }^{0.73}$. Our estimate was equivalent to $2 \cdot 82 \mathrm{mg} \mathrm{S} / \mathrm{kg}$ live weight $0^{0.73}$.

The quantity of DSI required to maintain the sheep at zero $S$ balance can be calculated from the endogenous US excretion. When $\mathrm{S}$ and energy balance are zero, DSI equals the US excretion, which can be calculated from equation (4) to equal $0.038 \div(\mathrm{r}-0.704)$ or $0.13 \mathrm{~g} \mathrm{~S} / \mathrm{d}$. A similar value can be calculated direct from equation (6). Zero $\mathrm{S}$ balance represents a negative $\mathrm{S}$ balance for the fleece-free tissues because wool grows and $S$ is secreted in wool even when sheep are in negative $S$ and energy balance. The $\mathrm{S}$ requirements for wool growth are frequently greater than those necessary to maintain the fleece-free tissues in S equilibrium. For example, a sheep growing $4 \mathrm{~g}$ clean wool/d, stores approximately $0.14 \mathrm{~g} \mathrm{~S} / \mathrm{d}$ in its fleece (Langlands \& Sutherland, 1973), and when at zero energy balance would require $0.60 \mathrm{~g} \mathrm{DSI} / \mathrm{d}$ (equation (6)). The requirement expressed in terms of DSI varies with the $\mathrm{S}$ content of the diet, and can be calculated from equation (3). If the diet contained $2 \mathrm{~g} \mathrm{~S} / \mathrm{kg}$ organic matter, the apparent S digestibility would be 0.504 , and the intake of $0.60 \mathrm{~g}$ DSI would be provided by an intake of $\mathrm{r} \cdot \mathrm{I} 9 \mathrm{~g} \mathrm{~S}$ and $595 \mathrm{~g}$ organic matter/d.

\section{REFERENCES}

Agricultural Research Council (1965). The Nutrient Requirements of Farm Livestock. No. 2. Ruminants. London: Agricultural Research Council.

Barrow, N. J. \& Lambourne, L. J. (1962). Aust. F. agric. Res. 13, 461.

Bird, P. R. (1972a). Aust. F. biol. Sci. 25, 195.

Bird, P. R. ( I972 b). Aust. F. biol. Sci. 25, 817.

Draper, N. R. \& Smith, H. (1966). Applied Regression Analysis. New York: Wiley.

Elliott, R. C., Reed, W. D. C. \& Topps, J. H. (I964). Br. F. Nutr. 18, 5 I 9.

Hogan, J. P. \& Weston, R. H. (r968). Proc. Aust. Soc. Anim. Prod. 7, 364.

Langlands, J. P., Corbett, J. L., McDonald, I. \& Pullar, J. D. (1963). Anim. Prod. 5, I.

Langlands, J. P. \& Sutherland, H. A. M. (1973). Br. F. Nutr. 30, 529. 
Mottershead, B. E. ( ( 971). Lab. Pract. 20, 483.

Playne, M. J. \& Haydock, K. P. (1972). Aust. 9. exp. Agric. Anim. Husb. 12, 365.

Robinson, J. J. \& Forbes, T. J. (I966). Br. J. Nutr. 20, 263.

Van Niekerk, B. D. H., Smith, D. W. W. Q. \& Oosthysen, D. (1967). Proc. S. Afr. Soc. Anim. Prod. 6, ro8.

Walker, D. J. \& Nader, C. J. (1 968). Appl. Microbiol. 16, i 124.

Walker, D. M. \& Faichney, G. J. (I964). Br. F. Nutr. 18, 20 I. 